\title{
In vitro Antioxidant and anti-inflammatory properties of selected Moroccan medicinal plants
}

\author{
Eimad dine Tariq BOUHLALI ${ }^{1 *}$, Khalid SELLAM ${ }^{1}$, Mohamed BAMMOU $^{1}$, Chakib ALEM ${ }^{2}$, Younes FILALI- \\ ZEHZOUTI $^{1}$
}

${ }^{1}$ Team of Biology, Health and Environment, Faculty of Science and Technology Errachidia. Morocco.

${ }^{2}$ Team of Biochemistry of Natural Products, Faculty of Science and Technology Errachidia. Morocco.

\begin{tabular}{l} 
ARTICLE INFO \\
\hline Article history: \\
Received on: $11 / 11 / 2015$ \\
Revised on: 04/12/2015 \\
Accepted on: $30 / 01 / 2016$ \\
Available online: $28 / 05 / 2016$ \\
\hline Key words: \\
Cuminum cyminum; Lawsonia \\
inermis L.; Rosa damascena; \\
antioxidant; anti-inflammatory.
\end{tabular}

\begin{abstract}
The aim of the present study was to examine the antioxidant and anti-inflammatory activities of three Moroccan ethno medicinally important plants. The antioxidant activity was performed using $\beta$-Carotene bleaching assay, $\mathrm{DPPH}, \mathrm{ABTS}$ and Ferric reducing assays. In vitro anti-inflammatory assays was also studied through the evaluation of membrane stabilization potential and inhibition of protein denaturation. Results revealed that Lawsonia inermis $L$ leaves extract had significantly higher phenolics-content (5.23 g GAE/100g DW) and exhibited the highest antioxidant activity based on DPPH $\left(\mathrm{IC}_{50}=18.26 \mu \mathrm{g} / \mathrm{mL}\right)$. The highest flavonoids content was found in Rosa damascena. L flower (3.97 RE/100g DW) which shows the highest antioxidant activity based on ABTS (30.39 mmol TE/100g DW), FRAP (38.54 mmol TE/100gDW) and $\beta$-Carotene bleaching assay $\left(\mathrm{IC}_{50}=56.33 \mu \mathrm{g} / \mathrm{mL}\right)$. Concerning the anti-inflammatory potency, the highest membrane stabilization effect was found in Rosa damascena. L flower $\left(\mathrm{IC}_{50}=125.02 \mu \mathrm{g} / \mathrm{mL}\right)$ and the highest anti-denaturation of protein effect was found in Lawsonia inermis $L$ leaves extract $\left(\mathrm{IC}_{50}=103.21 \mu \mathrm{g} / \mathrm{mL}\right)$. Consequently, to conclude flavonoids and related phenolics present in studied plant materials may possibly be responsible for the important antiinflammatory and antioxidant activities.
\end{abstract}

\section{INTRODUCTION}

Inflammation is the normal response of body's immune system that occurs in vascular tissues against harmful stimuli such as pathogens, cellular damage and irritants (Ferrero-Miliani et al., 2007). Chronic inflammation is usually associated with an increase in reactive nitrogen and oxygen species production bringing about an oxidative stress initiated by an imbalance between reactive oxygen species and the biological system's defence able to eliminate these free radicals (Salman and Ashraf, 2013). This oxidative stress has been involved in several diseases including cancer, neurodegenerative diseases, atherosclerosis, malaria, chronic fatigue syndrome and rheumatoid arthritis (Chaitanya et al., 2010). Recently there has been an extensive interest in the therapeutic potential of medicinal plants as antioxidants in scavenging such free radical-induced tissue injury (Pourmorad et al., 2006). In southeast Morocco traditional medical system, plants such as Lawsonia inermis L leaves, Rosa damascene flowers, Cuminum cyminum seed are used to treat

\footnotetext{
* Corresponding Author

Eimad dine Tariq BOUHLALI, Team of Biology, Health and

Environment, Faculty of Science and Technology Errachidia, Morocco.

Email: bouhlali.eimad@gmail.com
}

gastric pains, menstrual disorder, fever, oedema, rheumatism and bronchitis. Several researchers have reported the different biological actions of Lawsonia inermis $\mathrm{L}$ leaves, Rosa damascena flowers, Cuminum cyminum seed using various in-vitro and invivo test models.

Lawsonia inermis $\mathrm{L}$ leaves have been found to exhibit an antioxidant, antimicrobial, antifungal, antidiabetic, anthelminthic, antitrypanosomal, abortifacient, and anticancer activities as well as immunomodulatory, hepatoprotective and wound healing effects (Makhija et al., 2011). Cuminum cyminum seeds have been revealed to have an antioxidant, antimicrobial, anticarcinogenic, antidiabetic, estrogenic, anti-osteoporotic, antitussive, antiepileptic, analgesic, antiaggregatory and Immunomodulatory proprieties (Johri. 2011). The experimental studies conducted on Rosa damascena have been shown to have an antioxidant, antibacterial, antitussive, antidiabetic, anti-HIV, analgesic, anticonvulsant, anti-anxiety, anti-depressant, hypnotic effects (Boskabady et al., 2011).

Based on the traditional claims surrounding Rosa damascena, Lawsonia inermis $\mathrm{L}$ and Cuminum cyminum, The aim of this research was to examine the antioxidant and antiinflammatory activities through several in vitro methods. 


\section{MATERIALS AND METHODS}

\section{Plant material}

The plant materials were harvested during their optimal season; flowers of Rosa damascena were collected in May 2013, Lawsonia inermis L leaves in June 2013 and the seeds of Cuminum cyminum were collected during May 2013.

To insure that there are no impurities on the surface of plant materials, they were washed under running tap water then were air dried under shade using ventilator to dry more quickly. The dried plants were ground to powder using an electrical grinder.

\section{Preparation of rich polyphenol extracts}

Five grams of each powdered sample were kept in a glass flask and the volume was made up to $100 \mathrm{~mL}$ with the methanolwater $(4: 1, \quad \mathrm{v} / \mathrm{v})$, after content dissolving. Ultrasonic extraction was performed in a sonication water bath (Branson Ultrasonic Cleaner 2510R) with a working frequency and temperature fixed at $40 \mathrm{KHz}$ and $69^{\circ} \mathrm{C}$ respectively for one hour.

At the end of sonication, the suspension was cooled to ambient temperature and then filtered using Whatman no. 4 filter paper. The collected filtrate was then used for the determination of total phenolics compounds and to evaluate the antioxidants and anti-inflammatory activity.

\section{Measurement of total polyphenolic content.}

The total phenolic contents in plant material were measured according to the method described by (Bouhlali et al., 2015a). Five hundred $\mu \mathrm{L}$ of Folin-Ciocalteau reagent (10-fold diluted with water) was mixed with $100 \mu \mathrm{L}$ of diluted filtrate, and then $400 \mu \mathrm{L}$ of aqueous sodium carbonate solution $(7.5 \% \mathrm{w} / \mathrm{v})$ was added.

The mixture was allowed for $60 \mathrm{~min}$ at room temperature then the absorbance was measured at $765 \mathrm{~nm}$. The calibration curve was prepared using Gallic acid. The total phenolic compounds were expressed as Gallic acid equivalent in $\mathrm{g} / 100 \mathrm{~g}$ dry weight (DW) of plant material.

\section{Measurement of flavonoid content:}

The total flavonoid content of plant material was determined by the method of (Kim et al., 2003). Five hundred $\mu \mathrm{L}$ of diluted filtrate was mixed with $2 \mathrm{~mL}$ of distilled water. Then $150 \mu \mathrm{L}$ of aqueous sodium nitrite solution (5\% w/v) was added, followed by $150 \mu \mathrm{L}$ of aqueous aluminum chloride solution (10\% $\mathrm{w} / \mathrm{v})$. Test tubes were incubated for $5 \mathrm{~min}$ at room temperature, and then $1 \mathrm{~mL}$ of sodium hydroxide (1M) was added to the mixture and then the final volume was made up to $5 \mathrm{~mL}$ with distilled water. The mixture was vortexed and the absorbance was determined at $510 \mathrm{~nm}$.

The absorbance was calibrated to a standard curve of Rutin solution and the results were expressed as $g$ Rutin equivalents (RE)/100 g of dry weight (DW) of plant material.

\section{ABTS radical scavenging assay}

The ABTS assay was done using the method of $(\operatorname{Re} e t$ al., 1999). The ABTS radical cations (ABTS+) were produced by reacting aqueous solution of ABTS $(7 \mathrm{mM})$ with an aqueous solution of potassium persulphate $(2.45 \mathrm{mM})$. The mixture was left at the ambient temperature in the dark for 12-16 hours before use; the result solution was diluted with distilled water to obtain 0.700 \pm 0.005 at $734 \mathrm{~nm}$ in the absorbance. $30 \mu \mathrm{L}$ of the sample added to $3 \mathrm{~mL}$ of the ABTS solution was allowed at ambient temperature. After 6 min the absorbance at $734 \mathrm{~nm}$ was recorded immediately. Trolox solution was used to prepare the standard curve and the total antioxidants were expressed as mmol of Trolox equivalents per $100 \mathrm{~g}$ of dry weight (DW) of plant part.

\section{DPPH radical scavenging activity}

Radical scavenging activity of plant material against stable DPPH was evaluated using the method described by (Bouhlali et al., 2015b) with slight modifications. The reaction mixture contained $100 \mu \mathrm{L}$ of filtrate at different concentration and $1.9 \mathrm{~mL}$ of methanolic DPPH $(0.3 \mathrm{mM})$. The result mixtures were left at room temperature for $20 \mathrm{~min}$ and the absorbance was measured at $517 \mathrm{~nm}$. The $\mathrm{IC}_{50}$ (concentration providing $50 \%$ inhibition) values were calculated from the plotted graph of scavenging activity against the concentrations of the samples.

$\%$ inhibition $=\frac{(\text { Abs }(\text { control })-\text { Abs }(\text { sample }))}{\text { Abs }(\text { control })} X 100$

Abs control is the absorbance without extract; Abs sample is the absorbance of the extract or standard.

\section{Ferric reducing antioxidant power assay}

The ferric reducing activity of the plant material extract was estimated based on the method of (Benzie and Strain, 1999). The FRAP reagent was prepared by mixing $50 \mathrm{~mL}$ of acetate buffer $(0.3 \mathrm{M}, \mathrm{pH} 3.6), 5 \mathrm{~mL}$ of Ferric chloride solution $\left(\mathrm{FeCl}_{3}\right)$ $(20 \mathrm{mM})$ and $5 \mathrm{~mL}$ of TPTZ (2,4,6-Tripyridyl-s-Triazine) solution (10mM) prepared in $\mathrm{HCl}(40 \mathrm{mM}) .2 \mathrm{~mL}$ of the freshly prepared FRAP reagent was added to the $10 \mu \mathrm{L}$ of extract. Then the absorbance was measured at $593 \mathrm{~nm}$ against the blank after 10 minutes at ambient temperature. Trolox was used to prepare the standard curve. The result was expressed as Trolox equivalent in $\mathrm{mmol} / 100 \mathrm{~g}$ of dry weight (DW) plant parts.

\section{$\beta$-Carotene bleaching assay}

The $\beta$-carotene bleaching inhibition method was carried out using the method of (Shahidi et al., 2001). Two mg of $\beta$ carotene were dissolved in ten $\mathrm{mL}$ of chloroform then four $\mathrm{mL}$ of this solution were pipetted into a round-bottom flask, which contains forty $\mathrm{mg}$ of linoleic acid and five hundred $\mathrm{mg}$ of Tween 40. The chloroform was then, evaporated under vacuum at $40{ }^{\circ} \mathrm{C}$ and one hundred $\mathrm{mL}$ of oxygenated water was added and vigorously shaken to yield fresh emulsion one $\mathrm{mL}$ of the emulsion was transferred into test tubes containing one hundred $\mu \mathrm{L}$ of diluted filtrate and incubated in a water bath at $50{ }^{\circ} \mathrm{C}$ then the 
absorbance was measured at $470 \mathrm{~nm}$ immediately $(\mathrm{t}=0 \mathrm{~min})$ and after $120 \mathrm{~min}$ of incubation against a blank which contains the emulsion without $\beta$-carotene. The antioxidant activity of plants was compared to the positive control, which was BHT in this assay. The $\beta$-carotene bleaching inhibition $(\%)$ of the analyzed solution was calculated via the following formula:

$\beta$ carotene bleaching inhibition (\%)

$$
=\frac{\beta \text { carotene content after } 2 \mathrm{~h} \text { assay }}{\text { Initial } \beta \text { carotene content }} \times 100
$$

The $\mathrm{IC}_{50}$ was calculated using a standard curve between the plant material concentration and the percentage of $\beta$-carotene bleaching inhibition.

\section{Inhibition of albumin denaturation}

The Inhibition of albumin denaturation was assessed according to the modified method of (Chandra et al., 2012). Briefly, one $\mathrm{mL}$ of $1 \%$ bovine serum albumin prepared in PBS (phosphate-buffered saline, $\mathrm{pH}$ 6.4) was added to one $\mathrm{mL}$ of varying concentrations of plant filtrate. This mixture was left at ambient temperature for $20 \mathrm{~min}$ and then heated at $70^{\circ} \mathrm{C}$ for $5 \mathrm{~min}$. The resulting mixture was cooled down to the ambient temperature and their turbidities were read at $660 \mathrm{~nm}$. The same procedure was repeated using doubledistilled water and the Diclofenac as control and standard respectively. The Percentage inhibition (IP\%) of protein denaturation was calculated as follows:

Percentage inhibition (IP\%)

$$
=\frac{(\text { Abs Control }- \text { Abs Sample })}{\text { Abs control }} X 100
$$

Abs control is the absorbance without plant material; Abs sample is the absorbance of the plant material or standard.

\section{The membrane stabilization potential}

The membrane stabilization potential was determined according to the method described by (Murugan and Parimelazhagan, 2014). The sterilized Alsever's solution prepared by dissolving $0.05 \%$ citric acid, $0.42 \%$ of sodium chloride, $0.8 \%$ sodium citrate, and $2 \%$ dextrose in distilled water was mixed with equal volume blood collected from healthy human volunteers who did not use any NSAIDS for fifteen day's before blood collecting. After centrifugation at $3000 \mathrm{rpm}$ of result blood solution the cell pellet was washed with isotonic Saline $(9 \mathrm{~g} / \mathrm{L})$ which was used then to prepare a suspension containing $10 \%$ cell pellet.

The reaction mixture contains $1 \mathrm{~mL}$ of phosphate buffer, $0.5 \mathrm{~mL}$ of Diclofenac of plant extract at various concentrations (50, 100, 200, 400 and $800 \mu \mathrm{g} / \mathrm{mL}), 0.5 \mathrm{~mL}$ of blood suspension $(10 \%)$ and $2 \mathrm{ml}$ of hypotonic saline $(3.6 \mathrm{~g} / \mathrm{L})$. After incubation for $30 \mathrm{~min}$ at $37^{\circ} \mathrm{C}$, the mixtures were centrifuged at $3000 \mathrm{rpm}$ and the hemoglobin content of supernatant was estimated by a spectrophotometer at $560 \mathrm{~nm}$.

\section{Statistical analysis}

The results were statistically evaluated by one way analysis of variance (ANOVA) using StatView 5.0 software. The experimental results were reported as mean $\pm \mathrm{SE}$ (standard error) $(n=6)$. Pearson's correlation coefficient $\left(R^{2}\right)$ was used to measure the association between two variables. Differences at $\mathrm{p}<0.05$ were considered significant.

\section{RESULTS AND DISCUSSION}

\section{Total phenolic and flavonoid content}

The results of total polyphenolic and flavonoid contents from studied plant material are depicted in Table 1. The highest phenolic content was found in Lawsonia inermis $L$ leaves extract (5.31 g GAE/100 g DW) which is followed by Rosa damascena. L flower (4.89 g GAE/100g DW) and the lowest was found in Cuminum cyminum seeds extract (1.07 g GAE/100g DW). Regarding total flavonoid contents the highest level was found in Rosa damascena. L flower (3.97 RE/100g DW) which was higher than those of Lawsonia inermis L. leaves extract (3.62 g RE/100g DW) and Cuminum cyminum seeds extract (0.52 g RE/100g DW).

The result reported by (Tan et al., 2013) for Lawsonia inermis leaves (5.55 g GAE/100 g DW), by (Rebey et al., 2012) for Cuminum cyminum seeds (1.45-1.86 g GAE/100 g DW) and by (Bayram et al., 2015) for Rosa damascena flower (4.31 g GAE/100 g DW) are very close to our results. Several studies link the antioxidant activity of medicinal plant to their phenolics content due to their redox properties, which plays an important role in neutralizing and scavenging free radicals, quenching singlet and triplet oxygen, or decomposing peroxides (Ghasemzadeh et al., 2010).

Table 1: Antioxidant activity, total phenolic content and total flavonoid of studied plants materials

\begin{tabular}{lcccc}
\hline & $\begin{array}{c}\text { Total } \\
\text { Phenolic } \\
\text { content } \\
\text { g GA/100g } \\
\text { DW }\end{array}$ & $\begin{array}{c}\text { Total } \\
\text { Flavonoid } \\
\text { content } \\
\text { g RE / 100g } \\
\text { DW }\end{array}$ & $\begin{array}{c}\text { FRAP } \\
\text { mmol } \\
\text { TE/100g } \\
\text { DW }\end{array}$ & $\begin{array}{c}\text { ABTS } \\
\text { mmol } \\
\text { TE/100g } \\
\text { DW }\end{array}$ \\
\hline $\begin{array}{l}\text { Lawsonia } \\
\text { inermis } \boldsymbol{L}\end{array}$ & $5.31 \pm 0.16$ & $3.62 \pm 0.15$ & $33.06 \pm 0.19$ & $26.84 \pm 1.19$ \\
$\begin{array}{l}\text { Rosa } \\
\text { damascena }\end{array}$ & $4.89 \pm 0.13$ & $3.97 \pm 0.11$ & $38.54 \pm 0.32$ & $30.39 \pm 0.84$ \\
$\begin{array}{l}\text { Cuminum } \\
\text { cyminum }\end{array}$ & $1.07 \pm 0.07$ & $0.52 \pm 0.04$ & $6.89 \pm 0.51$ & $2.79 \pm 0.43$ \\
\hline $\begin{array}{l}\text { Values are mean } \\
\text { at p }<0.05 . \text { GAE }- \text { Gallic acid equivalents. RE }- \text { Rutin equivalents. TE- Trolox } \\
\text { equivalents }\end{array}$
\end{tabular}

\section{Antioxidant activities}

Because the plant extract contains a wide range of antioxidant compounds, which may act through different mechanisms and because there is no single method can evaluate the total antioxidant capacity of these medicinal plants. Hence, the antioxidant activity of selected plant materials was carried out using FRAP, ABTS and DPPH scavenging as well as $\beta$ carotene bleaching assay.

The ferric reducing antioxidant power (FRAP) is quick, simple, reproducible, linearly related to the molar concentration of the antioxidants and commonly used to study the antioxidant capacity of plant materials. This assay based on the ability of 
antioxidant to reduce ferric (III) iron to ferrous (II) iron through an electron transfer reaction (Shi et al., 2010). Table 1 showed that Rosa damascena extract (38.54 mM TE/100g plant material) was the most powerful to reduce the ferric ions into ferrous ions among studied plants, followed by Lawsonia inermis $L$ extract $(33.06 \mathrm{mM}$ TE/100g plant material) and Cuminum cyminum extract $(6.89 \mathrm{mM}$ $\mathrm{TE} / 100 \mathrm{~g}$ plant material). This reducing properties are associated with the presence of polyphenol and Flavonoids which may act as reductones as showed the significant linear correlation which is $\left(\mathrm{R}^{2}>0.930\right)$ between FRAP in one hand and phenolic and flavonoid content in the other hand (Table 3).

DPPH and ABTS methods are simple, precise, inexpensive and commonly used to assess the antioxidant activity of medicinal plant. The DPPH (2,2- diphenyl-1-picrylhydrazyl) and the ABTS (2,2'-azinobis(3-ethylbenzothiazoline 6-sulfonic acid)) in its radical form has a characteristic absorbance at $517 \mathrm{~nm}$ and $734 \mathrm{~nm}$ respectively, which vanishes after its reduction by electron or hydrogen donors. This reduction can be monitored by measuring the decrease in its absorbance at $517 \mathrm{~nm}$ and $734 \mathrm{~nm}$ (Shalaby and Shanab., 2013). As showed in Table 2 Rosa damascena extract was the most effective radical scavenger against both of DPPH $\left(\mathrm{IC}_{50}=27.48 \mu \mathrm{g}\right.$ of plant materiel $\left./ \mathrm{mL}\right)$ and ABTS (30.39 mM TE/100 g plant materiel). The lowest scavenging ability was observed in Cuminum cyminum extract with $\left(2.79 \mathrm{mM}\right.$ TE/100 g plant materiel) for ABTS assay and $\left(\mathrm{IC}_{50}\right.$ $=172.05 \mu \mathrm{g}$ of plant materiel $/ \mathrm{mL}$ ) for DPPH assay. Our result for Lawsonia inermis $L$ using DPPH assay agrees to those reported by (Guha et al., 2011). The result of FRAP and DPPH conducted on Rosa damascena is very high than those reported by (KalchevaKaradzhova et al., 2014). The results reported by Rebey et al., 2012 using DPPH and $\beta$-carotene bleaching methods for Cuminum cyminum seeds were very high than the results found in our study.

Concerning the $\beta$-carotene bleaching assay based on the reduction of the orange color intensity of $\beta$-carotene due to its reaction with peroxyl radical $(\mathrm{LOO} \bullet$ ) generated by linoleic acid in the presence of oxygen during incubation at $50^{\circ} \mathrm{C}$ (Moon and Shibamoto, 2009). The difference between the initial absorbance measured at the beginning and the absorbance after 120 min give information about the ability of plant material to inhibit the bleaching of the $\beta$-carotene solution. The plant antioxidants can disturb the degree of $\beta$-carotene bleaching through neutralization of linoleate-free radicals and other radicals formed in the system (Jayaprakasha et al., 2001). The results have shown that plant extract inhibited the $\beta$ - carotene bleaching in a dose dependent manner and the strength of inhibition varied between $(56.33 \mu \mathrm{g} / \mathrm{mL})$ for Rosa damascena extract which presented the lowest $\mathrm{IC}_{50}$ and Cuminum cyminum extract with the highest $\mathrm{IC}_{50}$ $(279.54 \mu \mathrm{g} / \mathrm{mL}$ ) (Table 2). It was speculated that Rosa damascena extract and Lawsonia inermis extract exhibited an interesting antioxidant activity, which is very close to a standard antioxidant (BHT) which possessed an $\mathrm{IC}_{50}=53.25 \mu \mathrm{g} / \mathrm{mL}$.

As shown in Table 3, there is a strong correlation between total polyphenol contents and the antioxidant activity as well as between total flavonoid contents and the antioxidant activity of samples $\left(\mathrm{R}^{2}>0.93\right)$. The strong correlation in this study confirms other studies which have exposed that antioxidant activities are associated with plants phenolic content which may act as singlet oxygen quenchers, reducing agents and hydrogen donors (Chang et al., 2001).

Table 2: Antioxidant activity based on DPPH radical scavenging activity and $\underline{\beta-C a r o t e n e ~ b l e a c h i n g ~ a s s a y ~}$

\begin{tabular}{lcc}
\hline & IC $_{\mathbf{5 0}}$ of DPPH & $\boldsymbol{\beta}$-carotene $\mathbf{I C}_{\mathbf{5 0}}$ \\
& $\boldsymbol{\mu g} / \mathbf{m L}$ & $\boldsymbol{\mu g} / \mathbf{m L}$ \\
\hline Lawsonia inermis $\boldsymbol{L}$ & $18.26 \pm 1.04$ & $71.32 \pm 5.63$ \\
Rosa damascena & $27.48 \pm 2.72$ & $56.33 \pm 4.37$ \\
Cuminum cyminum & $172.05 \pm 8.19$ & $279.54 \pm 11.67$ \\
BHT & $22.67 \pm 2.17$ & $53.25 \pm 3.62$ \\
\hline
\end{tabular}

Values are mean \pm SE (standard error). Results are statistically significant at $\mathrm{p}<0.05$.

BHT: Butylated hydroxytoluene

A high correlation was observed between ABTS, FRAP, DPPH and $\beta$-carotene bleaching methods (Table 3 ), suggesting a possible antioxidant activity relationship of the compounds that react in these methods although they have different reaction mechanisms. The strong correlation between FRAP and ABTS assays may be due to the same mechanism that they have and their similar redox potential $(0.70 \mathrm{~V}$ for ferric reduction and $0.68 \mathrm{~V}$ for reaction with ABTS) (Müller et al, 2011).

Table 3: Correlation phenolic and flavonoid content with antioxidant activities.

\begin{tabular}{|c|c|c|c|c|c|c|}
\hline & 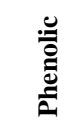 & 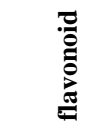 & $\frac{1}{a}$ & $\frac{\pi}{\frac{1}{2}}$ & 象 & 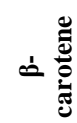 \\
\hline Phenolic & 1 & & & & & \\
\hline flavonoid & 0.967 & 1 & & & & \\
\hline FRAP & 0.937 & 0.995 & 1 & & & \\
\hline DPPH & 0.998 & 0.979 & 0.953 & 1 & & \\
\hline ABST & 0.957 & 0.999 & 0.998 & 0.971 & 1 & \\
\hline$\beta$-carotene & 0.978 & 0.998 & 0.989 & 0.987 & 0.996 & 1 \\
\hline
\end{tabular}

\section{The anti-inflammation activity}

The ethical challenges and the nonexistence of rationale to use animals for pharmacological research of new chemical compounds, when other suitable methods are available or could be investigated, pushed us to select the protein denaturation bioassay and membrane stabilization potential for in vitro evaluation of anti- inflammatory property activity of studied plant materials.

\section{The inhibition of protein denaturation}

Denaturation of tissue proteins is well-documented as one of the causes of inflammatory and arthritic diseases, through auto antigen production (Williams et al., 2008) and the ability of plant material to bring down the protein denaturation could be effective against inflammation diseases.

Maximum inhibition of heat induced albumin denaturation was observed from Lawsonia inermis $L$ leaves extract $\left(\mathrm{IC}_{50}=103.21 \mu \mathrm{g} / \mathrm{mL}\right)$ followed by Rosa damascena flowers extract $\left(\mathrm{IC}_{50}=129.04 \mu \mathrm{g} / \mathrm{mL}\right)$ and Cuminum cyminum seeds extract 
$\left(\mathrm{IC}_{50}=234.87 \mu \mathrm{g} / \mathrm{mL}\right)$. From the $\mathrm{IC}_{50}$ values, it becomes evident that Rosa damascena flowers extract and Lawsonia inermis $L$ leaves extract were very effective and close to Diclofenac $\left(\mathrm{IC}_{50}=\right.$ $86.75 \mu \mathrm{g} / \mathrm{mL}$ ) which is the standard anti-inflammation drug. The present findings showed that the plant material exhibited a concentration dependent inhibition of thermal protein denaturation. Mizushima and Kobayashi, (1968) using inflammatory drugs (salicylic acid, phenylbutazone etc.) found this inhibition dose dependent. The in vitro anti-inflammatory effect of plant material may be due to synergistic effect rather than single constituent of their polyphenols contents.

The reported results are in agreement with those reported by (Hajhashemi et al., 2010), (Alia et al., 1995) and (Bhat et al., 2014) who has found an important anti-inflammatory effect using Carrageenan-induced rat paw oedema assay by for Rosa damascena flowers, Lawsonia inermis $L$ leaves and Cuminum cyminum $L$ seeds respectively.

\section{The membrane-stabilizing potential}

In the course of inflammatory response, the activated neutrophil releases their lysosomal constituents such as proteases and bactericidal enzymes, which cause supplementary tissue inflammation and damage (Murugesh et al, 1981). Because human erythrocytes membranes are analogous to lysosomal membrane components (Mounnissamy et al., 2008), the inhibition of hypotonicity-induced hemolysis was used to investigate the antiinflammatory activity of plant material. Results presented in Fig.1 showed that Rosa damascena flowers extract exhibited the highest inhibition of hemolysis ( $\mathrm{IC}_{50}=125.02 \mu \mathrm{g} / \mathrm{mL}$ ) followed by Lawsonia inermis $L$ leaves extract $\left(\mathrm{IC}_{50}=170.24 \mu \mathrm{g} / \mathrm{mL}\right)$ and Cuminum cyminum seeds extract $\left(\mathrm{IC}_{50}=269.28 \mu \mathrm{g} / \mathrm{mL}\right)$. The results of erythrocytes protective effect found using these plant extract are lower to those of Diclofenac (IC50 $=94.77 \mu \mathrm{g} / \mathrm{mL}$ ). The membrane-stabilizing effect was established to increase with the increase drug and plant extract concentration. These plant extracts may act through a deformation of cells via their interaction with membrane proteins (Shinde et al., 1999) or other compound in the erythrocyte membranes, which provoke later alteration of the surface charges of the cells (Oyedapo et al., 2004). Knowing that changing in the form and volume of the cell is much related to the intracellular amount of calcium. The membrane protective effect of plant extract may be due to their ability to adjust the intracellular concentration of calcium into the erythrocytes (Chopade et al., 2012). Tannins and saponins are able to bind cations and other biomolecules (Oyedapo et al., 2001) hence their profound stabilizing effect.
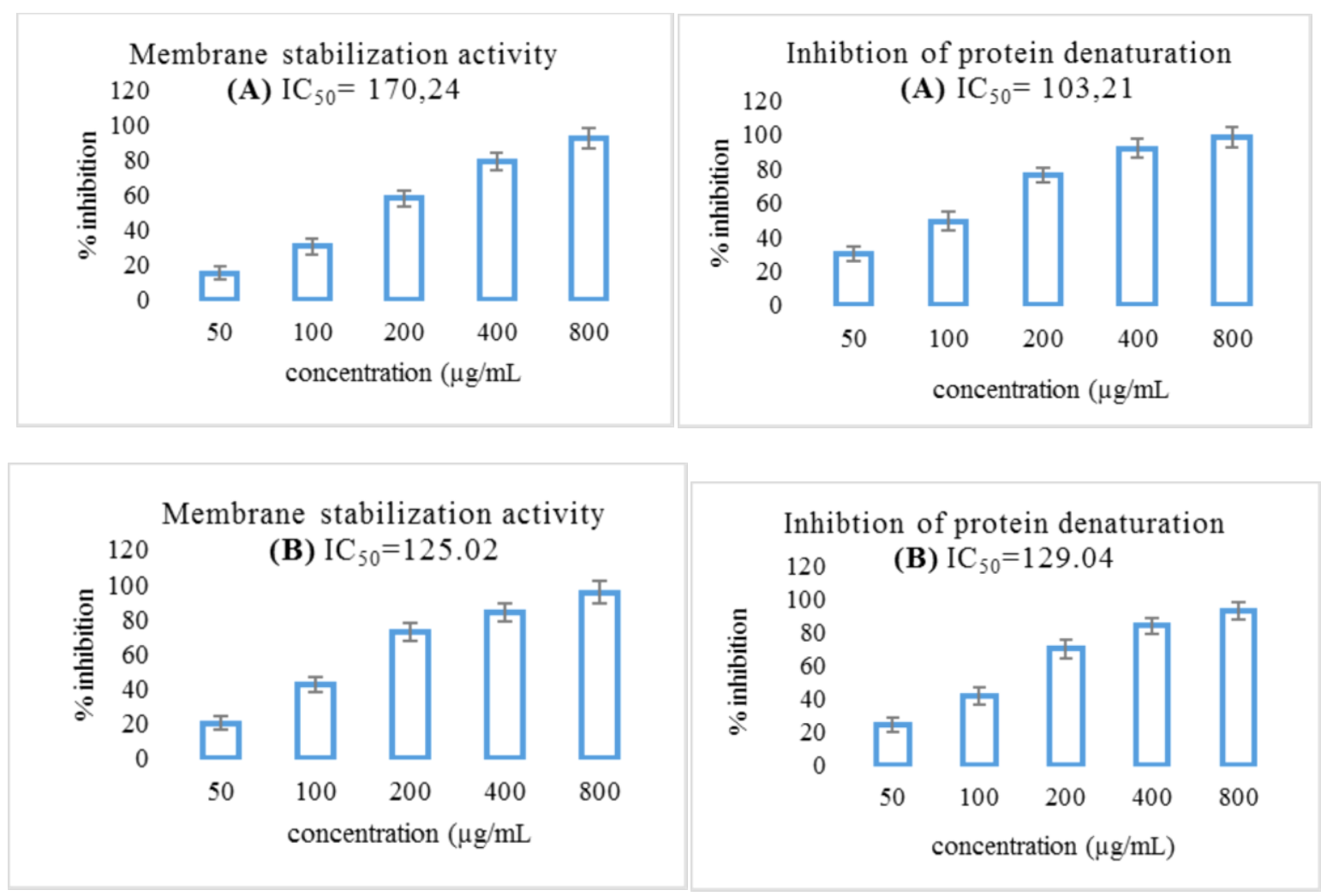

Fig. 1:.. 

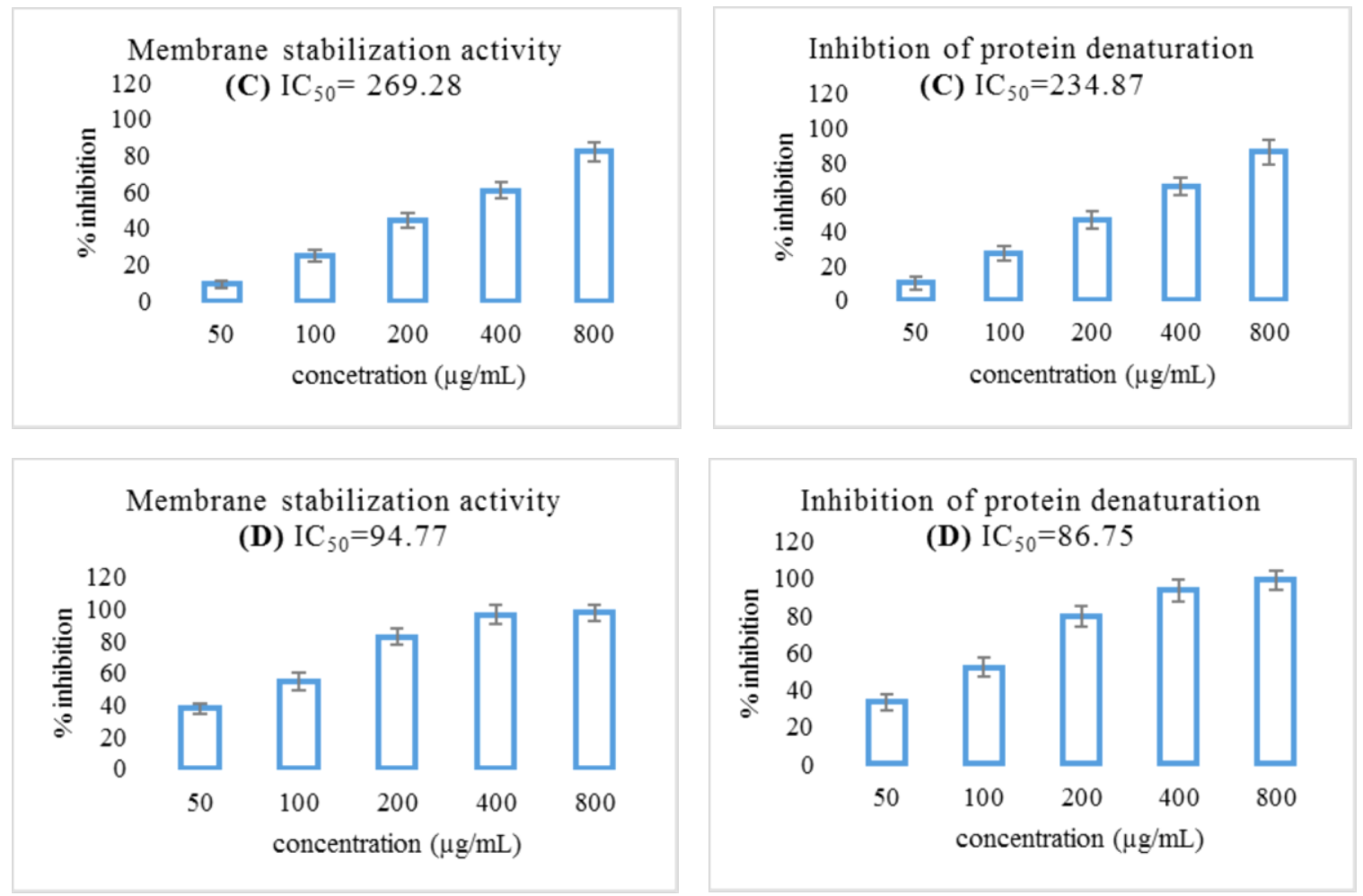

Fig. 1: Anti-inflammatory activity based on Membrane stabilization activity and Inhibition of protein denaturation.

A: Lawsonia inermis L, B: Rosa damascena, C: Cuminum cyminum, D : Diclofenac.

Values are mean \pm SE (standard error). Results are statistically significant at $\mathrm{p}<0.05$.

\section{CONCLUSION}

Our investigation clearly demonstrates that studied plant materials possess significant antioxidant activity against various antioxidant systems and potent anti inflammatory. The presence of various Polyphenols especially flavonoid may be responsible of these activities. The present study provides a scientific base for the ethno medicinal claims of plants. Further studies are recommended to isolate the active principle responsible for these activities.

\section{ACKNOWLEDGMENT}

The authors extend their thanks and appreciation to $\mathrm{Pr}$ Benlyas, Pr El boumeslouhi, Mr Bouhlali and Miss Ouirzgan for their assistance and valuable guidance.

\section{REFERENCES}

Alia BH, Bashir AK and Tanira MOM. Anti-inflammatory, antipyretic, and analgesic effects of Lawsonia inermis L. (henna) in rats. Pharmacology, 1995; 51(6): 356-363.

Bhat SP, Rizvi W \& Kumar A. Effect of Cuminum cyminum L. Seed Extracts on Pain and Inflammation. Journal of natural remedies, 2014; 14(2): 186-192.

Bayram O, Sagdic O \& Ekici L. Natural food colorants and bioactive extracts from some edible flowers. Journal of Applied Botany and Food Quality, 2015; 88(1).
Benzie IF \& Strain JJ. Ferric reducing/antioxidant power assay: direct measure of total antioxidant activity of biological fluids and modified version for simultaneous measurement of total antioxidant power and ascorbic acid concentration. Methods Enzymol, 1999: (299): 15-27.

Boskabady MH, Shafei MN, Saberi Z \& Amini S. Pharmacological effects of Rosa damascena. Iranian Journal of Basic Medical Sciences, 2011; 14(4): 295.

Bouhlali EDT, Ramchoun M, Alem C, Ghafoor K, Ennassir J \& Zegzouti YF. Functional composition and antioxidant activities of eight Moroccan date fruit varieties (Phoenix dactylifera L.). Journal of the Saudi Society of Agricultural Sciences, 2015a.

Bouhlali EDT, Alem C, Zegzouti YF. Antioxidant and antihemolytic activities of phenolic constituents of six moroccan date fruit (Phoenix dactylifera L.) syrups. Biotechnology an Indian Journal, 2015b; 12(1): 45-52.

Chaitanya KV. Role of oxidative stress in human health: an overview. j pharmacy res, 2010; 3(6).

Chandra S, Chatterjee P, Dey P \& Bhattacharya S. Evaluation of in vitro anti-inflammatory activity of coffee against the denaturation of protein. Asian Pac J Trop Biomed, 2012; 2(1): 178-180.

Chang ST, Wu JH, Wang SY, Kang PL, Yang NS \& Shyur LF. Antioxidant activity of extracts from Acacia confusa bark and heartwood. J. Agric. Food Chem, 2001; 49(7): 3420-3424.

Chopade AR, Somade PM \& Sayyad FJ. Membrane Stabilizing Activity and Protein Denaturation: A Possible Mechanism of Action for the Anti-Inflammatory Activity of Phyllanthus amarus. J Karad Inst Med Sci Univ, 2012; 1(1), 67-72.

Ferrero-Miliani L, Nielsen OH, Andersen PS \& Girardin SE. Chronic inflammation: importance of NOD2 and NALP3 in interleukin-1 $\beta$ generation. Clin Exp Immunol, 2007; 147(2), 227-235. 
Ghasemzadeh A. Jaafar HZ \& Rahmat A. Antioxidant activities, total phenolics and flavonoids content in two varieties of Malaysia young ginger (Zingiber officinale Roscoe). Molecules, 2010; 15(6): 4324-4333.

Guha G, Rajkumar V, Kumar RA \& Mathew L. Antioxidant activity of Lawsonia inermis extracts inhibits chromium (VI)-induced cellular and DNA toxicity. Evidence-Based Complementary and Alternative Medicine,2011.

Hajhashemi V, Ghannadi A \& Hajiloo M. Analgesic and antiinflammatory effects of Rosa damascena hydroalcoholic extract and its essential oil in animal models. Iranian journal of pharmaceutical research, 2010; 9(2): 163 .

Jayaprakasha, GK, Singh RP \& Sakariah KK. Antioxidant activity of grape seed (Vitis vinifera) extracts on peroxidation models in vitro. Food chem, 2001; 73(3): 285-290.

Johri RK. Cuminum cyminum and Carum carvi: An update. Pharmacognosy reviews, 2011; 5(9): 63.

Kalcheva-Karadzhova K, Shikov V, Mihalev K, Dobrev G, Ludneva D \& Penov N. 2014. Enzyme-Assisted Extraction of Polyphenols From Rose (Rosa damascena Mill.) Petals. Acta Universitatis Cibiniensis. Series E: Food Technology, 2014; 18(2): 65-72.

Kim DO, Jeong SW \& Lee CY. Antioxidant capacity of phenolic phytochemicals from various cultivars of plums. Food chem, 2003; 81(3), 321-326.

Makhija IK, Dhananjaya DR, Kumar VS, Devkar R, Khamar D, Manglani N \& Chandrakar S. Lawsonia inermis-From traditional use to scientific assessment. African journal of pharmaceutical sciences and pharmacy, 2011;2(1).

Mizushima Y \& Kobayashi M. Interaction of anti-inflammatory drugs with serum proteins, especially with some biologically active proteins. Journal of Pharmacy and Pharmacology, 1968; 20(3): 169-173.

Moon JK \& Shibamoto T. Antioxidant assays for plant and food components. J. Agric. Food Chem, 2009; 57(5): 1655-1666.

Mounnissamy VM, Kavimani S, Balu V \& Quine SD. Evaluation of Anti-inflammatory and Membrane stabilizing property of Ethanol Extract of Cansjera rheedii J. Gmelin (Opiliaceae). Iranian Journal of Pharmacology \& Therapeutics, 2008; 6(2): 235-237.

Müller L, Fröhlich K \& Böhm V. Comparative antioxidant activities of carotenoids measured by ferric reducing antioxidant power (FRAP), ABTS bleaching assay ( $\alpha$ TEAC), DPPH assay and peroxyl radical scavenging assay. Food Chem, 2011; 129(1): 139-148

Murugesh N, Vembar S \& Damodaran C. Studies on erythrocyte membrane IV: in vitro haemolytic activity of oleander extract. Toxicol Lett, 1981; 8(1): 33-38.

Murugan R \& Parimelazhagan T. Comparative evaluation of different extraction methods for antioxidant and anti-inflammatory properties from Osbeckia parvifolia Arn.-An in vitro approach. J King Saud Univ Sci 2014; 26(4): 267-275.

Oyedapo OO. Biological activity of Phyllanthus armarus extract on Pragrow-Dawley rats. Nig J Biochem Mol Biol, 2001; 26: 202-26.
Oyedapo OO, Akinpelu BA \& Orefuwa SO. Anti-inflammatory effect of Theobroma cacao, root extract. Trop Med Plants, 2004; 5: 161-6.

Pourmorad F, Hosseinimehr SJ \& Shahabimajd N. Antioxidant activity, phenol and flavonoid contents of some selected Iranian medicinal plants. Afr J Biotechnol, 2006;5(11).

Re R, Pellegrini N, Proteggente A, Pannala A, Yang M \& RiceEvans C. 1999. Antioxidant activity applying an improved ABTS radical cation decolorization assay. Free Radic Biol Med, 1999; 26(9): 1231-1237.

Rebey IB, Zakhama N, Karoui IJ \& Marzouk B. 2012. Polyphenol composition and antioxidant activity of cumin (Cuminum cyminum L.) seed extract under drought. Journal of food science, 2012; 77(6): 734-739.

Salman KA \& Ashraf S. Review: Reactive Oxygen Species: A link between chronic inflammation and cancer. As Pac J. Mol. Biol. Biotechnol, 2013; 21 (2) : 42-49.

Shahidi F, Chavan UD, Naczk M \& Amarowicz R. Nutrient distribution and phenolic antioxidants in air-classified fractions of beach pea (Lathyrus maritimus L.). J. Agric. Food Chem, 2001; 49(2), 926-933.

Shalaby EA \& Shanab SM. Comparison of DPPH and ABTS assays for determing antioxidant potential of water and methanol extracts of spirulina platensis. Indian J. Geo-Mar. Sci, 2013; 42, 556-564.

Shi F, Jia X, Zhao C, \& Chen Y. Antioxidant activities of various extracts from Artemisisa selengensis Turcz (LuHao). Molecules, 2010; 15(7): 4934-4946.

Shinde UA, Phadke AS, Nair AM, Mungantiwar AA, Dikshit VJ \& Saraf MN. Membrane stabilizing activity-a possible mechanism of action for the anti-inflammatory activity of Cedrus deodara wood oil. Fitoterapia, 1999; 70(3): 251-257.

Tan MC, Tan CP \& Ho CW. Effects of extraction solvent system, time and temperature on total phenolic content of henna (Lawsonia inermis) stems. International Food Research Journal, 2013 ; 20(6): 3117-3123.

Williams LA, O'Connar A, Latore L, Dennis O, Ringer S, Whittaker JA, Conrad J, Vogler B, Rosner H, Kraus W. The in vitro antidenaturation effects induced by natural products and non-steroidal compounds in heat treated (immunogenic) bovine serum albumin is proposed as a screening assay for the detection of anti-inflammatory compounds, without the use of animals, in the early stages of the drug discovery process. West Indian Med J, 2008; 57(4): 327-331.

\section{How to cite this article:}

Eimad dine Tariq BOUHLALI, Khalid Sellam, Chakib Alem, Younes Filali Zegzouti., In vitro Antioxidant and anti-inflammatory properties of selected Moroccan medicinal plants. J App Pharm Sci, 2016; 6 (05): 156-162. 